\title{
Development and Validation of Spectrophotometric Methods for the Determination of Glibenclamide
}

\section{Mukthinuthalapati Mathrusri Annapurna*, Peethala Prathyusha and Siyyadri Durga Saranya}

Department of Pharmaceutical Analysis and Quality Assurance GITAM Institute of Pharmacy, GITAM (Deemed to be University), Visakhapatnam, Andhra Pradesh, India.

*Corresponding Author: Mukthinuthalapati Mathrusri Annapurna, Department of Pharmaceutical Analysis and Quality Assurance GITAM Institute of Pharmacy, GITAM (Deemed to be University), Visakhapatnam, Andhra Pradesh, India.

Received: June 12, 2019; Published: July 22, 2019

DOI: $10.31080 /$ ASPS.2019.03.0349

\section{Abstract}

Glibenclamide (Glyburide) is an oral hypoglycemic drug. It acts by stimulating the pancreatic beta cells and secretes insulin. Often it is used to treat diabetes mellitus type 2. Three new spectrophotometric methods were developed for the assay of Glibenclamide tablet dosage forms using borate buffer $\mathrm{pH}$ 9.0, phosphate buffer $\mathrm{pH} 8.0$ and $\mathrm{pH} 2.0$ and the methods were validated. Shimadzu UV1800 Model UV-VIS double beam spectrophotometer was employed for the study. Glibenclamide Linearity was observed over the concentration range 1-20,1-100 and 1-100 $\mathrm{g} / \mathrm{ml}$ respectively in borate buffer $\mathrm{pH} 9.0$ (Method I), phosphate buffer pH 8.0 (Method II) and phosphate buffer $\mathrm{pH} 2.0$ (Method III) respectively. The linear regression equations are found to be $\mathrm{y}=0.0261 \mathrm{x}-0.0014\left(\mathrm{R}^{2}=\right.$ 0.9996), $y=0.0225 x+0.0088\left(R^{2}=0.9994\right)$ and $y=0.0249 x+0.0163\left(R^{2}=0.999\right)$ in method I, II and III respectively. The methods were validated by precision and accuracy studies and are suitable for the determining the assay of Glibenclamide tablets.

Keywords: Glibenclamide; Phosphate Buffers; Borate Buffer; Validation; ICH Guidelines

\section{Introduction}

Glibenclamide (Figure 1) is (5-chloro-N-(4-[N-(cyclo hexyl carbamoyl) sulphamoyl] phenethyl)-2-methoxy-benzamide) It is an antidiabetic drug administered orally. Glibenclamide is a sulphonylurea containing two moietiesa benzamide moiety and a sulphonylurea moiety. Glibenclamide is very poorly soluble in water and have a very good biomembrane permeability [1,2]. Glibenclamide was assayed by using different techniques such as spectrophotometry [3-7], spectrofluorimetry [8], LC-MS [9] and HPLC [10-14] methods for pharmaceutical dosage forms, nano emulsions $[15,16]$ and biological fluids [17-19].

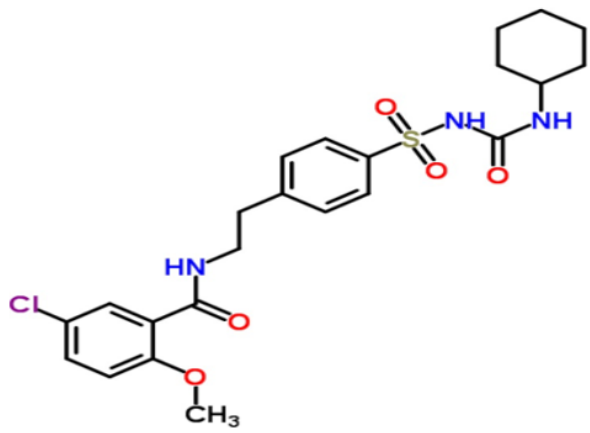

Figure 1: Chemical structure of Glibenclamide. 
The present article describes three new validated [20]. UV spectrophotometric methods for the determination of Glibenclamide in their tablet dosage forms.

\section{Materials and Methods}

- Preparation of borate buffer (pH 9.0): 6.2 grams of boric acid was dissolved in $500 \mathrm{ml}$ water, $\mathrm{pH}$ was adjusted to 9.0 with $1 \mathrm{M}$ sodium hydroxide (about $41.5 \mathrm{ml}$ ) and diluted with water to make up to $1000 \mathrm{ml}$ in a volumetric flask

- Preparation of phosphate buffer (pH 8.0): $50.0 \mathrm{ml}$ of $0.2 \mathrm{M}$ potassium di hydrogen phosphate was mixed with $46.8 \mathrm{ml}$ of $0.2 \mathrm{M}$ sodium hydroxide and sufficient water was added to make up the volume to $500 \mathrm{ml}$ in a volumetric flask.

- Preparation of phosphate buffer pH 2.0: Dissolve $0.136 \mathrm{~g}$ of potassium dihydrogen phosphate in $800 \mathrm{ml}$ of water, adjust the $\mathrm{pH}$ to 2.0 with hydrochloric acid and add sufficient water to produce $1000 \mathrm{ml}$.

- Instrumentation: Model No. UV-1800 double beam UVVIS spectrophotometer (Shimadzu) was used for the present study. All the solutions were scanned 200-400 $\mathrm{nm}$ keeping samples in quartz cuvettes. Glibenclamide is available as tables with brand names Afidex (Label claim: $2.5 \mathrm{mg}$ ) (Cadila pharmaceuticals Ltd) and Giclamide (Label claim: $5.0 \mathrm{mg}$ ) (Leben laboratories Pvt. Ltd).

Method validation

Linearity, Precision and accuracy studies

A series of Glibenclamide solutions 1-20, 1-100 and 1-100 $\mu \mathrm{g} /$ ml were prepared in borate buffer pH 9.0 (Method I), phosphate buffer pH 8.0 (Method II) and phosphate buffer pH 2.0 (Method III) from the stock solution respectively and scanned (200-400 nm) against their reagent blank. The absorption spectrum has shown $\lambda \max$ at $227 \mathrm{~nm}$ in all the three reagents for Method I, II and III. The absorbance of all these drug solutions were recorded at $\lambda$ max and calibration curves were plotted taking concentration on the $\mathrm{x}$-axis and the corresponding absorbance on the y-axis for Method I, II and III respectively.

Precision studies were performed on the same day and different days (Inter day and Intraday) $(n=6)$ and accuracy studies were carried out by spiking the solutions (50\%,100\%, and 150\%) and there by calculating the \% recovery in their respective buffers solutions for Method I, II and III respectively.
Assay of Glibenclamide tablets

Glibenclamide stock solution was prepared by dissolving $25 \mathrm{mg}$ of accurately weighed Glibenclamide in a $25 \mathrm{ml}$ volumetric flask in methanol $(1000 \mu \mathrm{g} / \mathrm{ml})$ and dilutions were made from the stock solution with borate buffer $\mathrm{pH} 9.0$, phosphate buffer $\mathrm{pH} 8.0$ and phosphate buffer $\mathrm{pH} 2.0$ respectively for Method I, II and III respectively. Two different brands of available Glibenclamide tablets were procured and the API was extracted with methanol. Dilutions were made from this solution and assay was performed.

\section{Results and Discussion}

Three new UV spectrophotometric methods were developed for the determination of Glibenclamide API and the three methods were applied for the Glibenclamide tablets. Literature survey was thoroughly done and the proposed three methods were compared with the previously published spectrophotometric methods and Table 1 describes the details. The characteristic UV absorption spectra of Glibenclamide obtained in three methods I, II and III has shown $\lambda$ max at $227 \mathrm{~nm}$ in borate buffer (Figure $2 \mathrm{~A}$ ), phosphate $\mathrm{pH}$ 8.0 (Figure 2B) and phosphate buffer pH 2.0 (Figure 2C) respectively.

\begin{tabular}{|l|c|c|c|}
\hline Reagent & $\begin{array}{c}\text { Linearity } \\
(\boldsymbol{\mu g} / \mathbf{m l})\end{array}$ & $\begin{array}{c}\lambda_{\text {max }} \\
(\mathbf{n m})\end{array}$ & References \\
\hline Distilled water & $1-5$ & 276 & 3 \\
\hline Ethanol and Water (1:5) & $2-14$ & 230 & 4 \\
\hline Ethanol & $3-15$ & 229.5 & 5 \\
\hline Chloroform & $5-30$ & 242 & 6 \\
\hline $\begin{array}{l}\text { Methanol and Water } \\
\text { 50:50, v/v) }\end{array}$ & $10.0-70$ & 308 & 7 \\
\hline $\begin{array}{l}\text { Ethanol (Spectrofluorim- } \\
\text { etry) }\end{array}$ & $1.4-10$ & 354 & 8 \\
\hline $\begin{array}{l}\text { Borate buffer pH- 9 } \\
\text { Phosphate buffer pH -8 } \\
\text { Phosphate buffer pH-2 }\end{array}$ & $0.5-20$ & 227 & Present \\
work
\end{tabular}

Table 1: Comparison of spectrophotometric methods published with the present. 


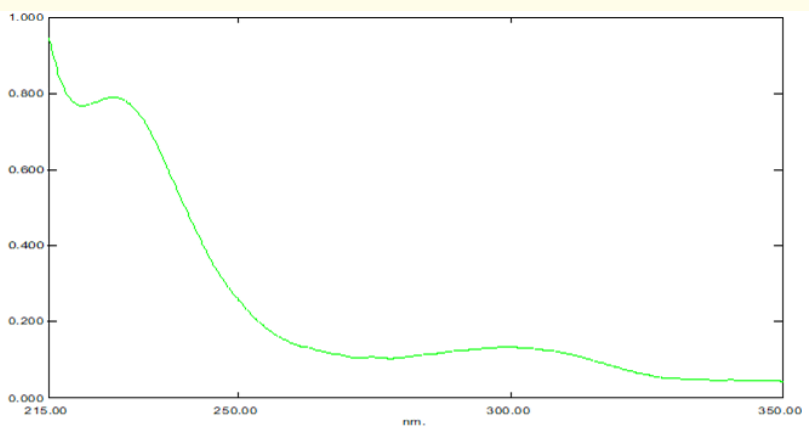

Figure 2A: Absorption spectra of Glibenclamide $(60 \mu \mathrm{g} / \mathrm{ml})$ in Borate buffer ( $\mathrm{pH}$ 9.0).

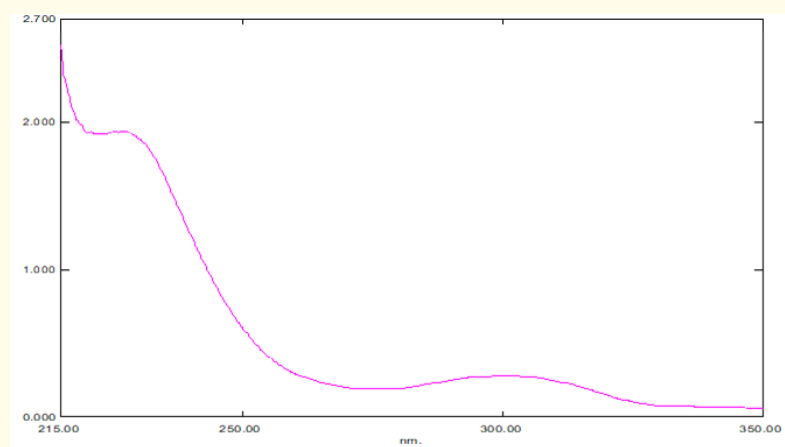

Figure 2B: Absorption spectra of Glibenclamide $(100 \mu \mathrm{g} / \mathrm{ml})$ in Phosphate buffer ( $\mathrm{pH}$ 8.0).

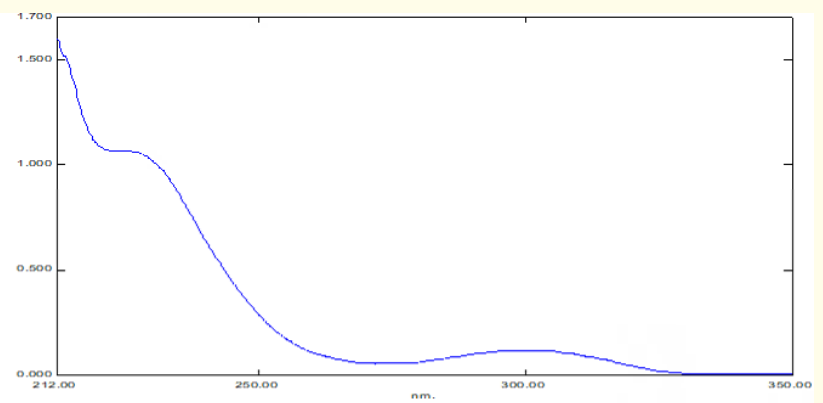

Figure 2C: Absorption spectra of Glibenclamide ( $40 \mu \mathrm{g} / \mathrm{ml})$ in Phosphate buffer ( $\mathrm{pH}$ 2.0).
Method validation

Beer-Lambert's law was obeyed over the concentration range 1-20, 1-100 and 1-100 $\mu \mathrm{g} / \mathrm{ml}$ in borate buffer $\mathrm{pH} 9.0$, phosphate buffer pH 8.0 and phosphate buffer $\mathrm{pH} 2.0$ (Table 2) respectively. The linear regression equations are found to be $\mathrm{y}=0.0261 \mathrm{x}-$ $0.0014\left(R^{2}=0.9996\right), y=0.0225 x+0.0088\left(R^{2}=0.9994\right)$ and $y=$ $0.0249 x+0.0163\left(R^{2}=0.999\right)$ in borate buffer (Figure $3 A$ ), phosphate pH 8.0 (Figure 3B) and phosphate buffer pH 2.0 (Figure 3C) respectively.

\begin{tabular}{|l|c|c|c|}
\hline Conc $(\boldsymbol{\mu g} / \mathbf{m l})$ & Method I & Method II & Method III \\
\hline 0.5 & 0.018 & 0.0128 & 0.0123 \\
\hline 1 & 0.0261 & 0.0225 & 0.0262 \\
\hline 1.5 & 0.032 & 0.0342 & 0.0482 \\
\hline 2 & 0.048 & 0.0452 & 0.050 \\
\hline 2.5 & 0.065 & 0.056 & 0.0622 \\
\hline 5 & 0.128 & 0.128 & 0.1250 \\
\hline 10 & 0.258 & 0.263 & 0.31 \\
\hline 20 & 0.523 & 0.5 & 0.544 \\
\hline 40 & - & 0.9 & 1.061 \\
\hline 60 & - & 1.33 & 1.531 \\
\hline 80 & - & 1.836 & 2.007 \\
\hline 100 & - & 2.255 & 2.470 \\
\hline
\end{tabular}

Table 2: Linearity of Glibenclamide.

The percentage RSD in intra-day precision was found to be 0.60-0.77, 0.56-0.76 and 0.48-1.30 whereas for inter-day precision it was $0.38-0.78,0.22-0.76$ and $0.36-1.30$ for Method I, II and III respectively which is less than 2.0 proving that the methods are precise. The \% RSD in accuracy studies was found to be less than 2.0 and the \% recovery was found to be 99.49-99.71, 99.26-99.5 and 99.34-99.78 indicating that the methods are accurate. The optical characteristics observed for all the three methods was shown in Table 3. 
Development and Validation of Spectrophotometric Methods for the Determination of Glibenclamide

\begin{tabular}{|c|c|c|c|c|}
\hline \multicolumn{2}{|c|}{ Parameters } & Method I & Method II & Method III \\
\hline \multicolumn{2}{|l|}{ Reagent } & Borate buffer $\mathrm{pH} 9$ & Phosphate buffer pH 8 & Phosphate buffer $\mathrm{pH} 2$ \\
\hline \multicolumn{2}{|c|}{ Linearity range $(\mu \mathrm{g} / \mathrm{ml})$} & $0.5-20$ & $0.5-100$ & $0.5-100$ \\
\hline \multicolumn{2}{|c|}{$\lambda \max (\mathrm{nm})$} & 227 & 227 & 227 \\
\hline \multicolumn{2}{|c|}{$\begin{array}{l}\text { Molar extinction coefficient } \\
\text { (Litre/mole/cm) }\end{array}$} & $1.27453 \times 104$ & $1.29923 \times 104$ & $1.5314 \times 104$ \\
\hline \multicolumn{2}{|c|}{$\begin{array}{l}\text { Sandell's sensitivity } \\
\text { ( } \mu \mathrm{g} / \mathrm{cm} 2 / 0.001 \text { absorbance unit) }\end{array}$} & 0.0387 & 0.0380 & 0.0322 \\
\hline \multicolumn{2}{|c|}{ Slope } & 0.0261 & 0.0225 & 0.0249 \\
\hline \multicolumn{2}{|l|}{ Intercept } & 0.0014 & 0.0088 & 0.0163 \\
\hline \multicolumn{2}{|c|}{ Correlation coefficient } & 0.9996 & 0.9994 & 0.999 \\
\hline \multirow{2}{*}{$\begin{array}{l}\text { Precision } \\
(\% \text { RSD })\end{array}$} & Interday & $0.38-0.78$ & $0.22-0.76$ & $0.36-1.3$ \\
\hline & Intraday & $0.60-0.77$ & $0.56-0.76$ & $0.48-1.3$ \\
\hline \multicolumn{2}{|c|}{ Accuracy (\% Recovery) } & $99.49-99.71$ & $99.26-99.5$ & 99.34-99.78 \\
\hline \multicolumn{2}{|c|}{ Assay $(\%)$} & $99.66-99.84$ & $99.68-99.82$ & $99.58-99.92$ \\
\hline
\end{tabular}

Table 3: Optical characteristics of Glibenclamide.

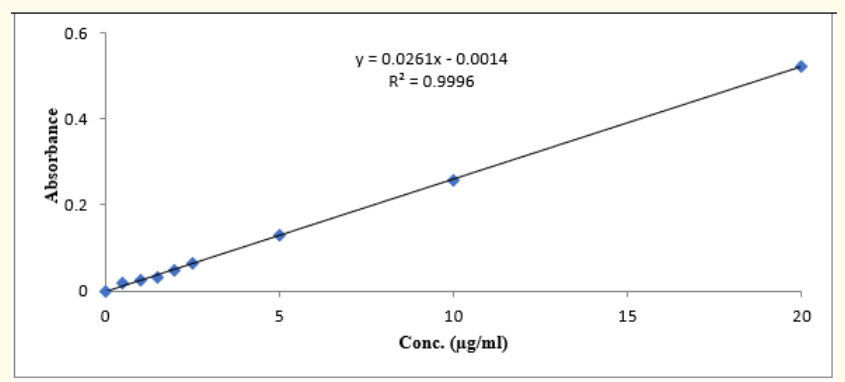

Figure 3A: Calibration curve of Glibenclamide in Borate buffer (pH 9.0).

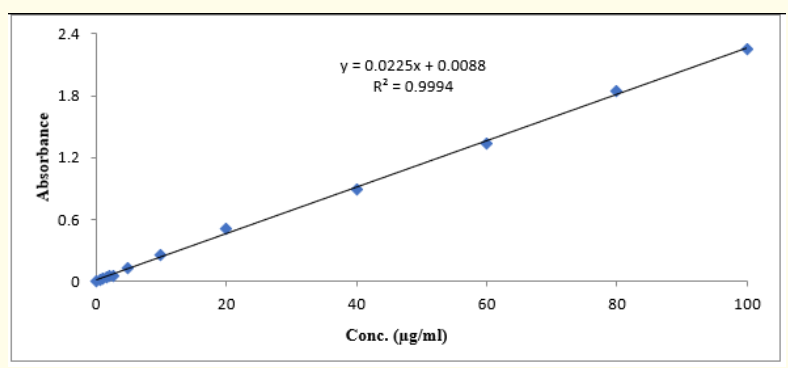

Figure 3B: Calibration curve of Glibenclamide in Phosphate buffer (pH 8.0).

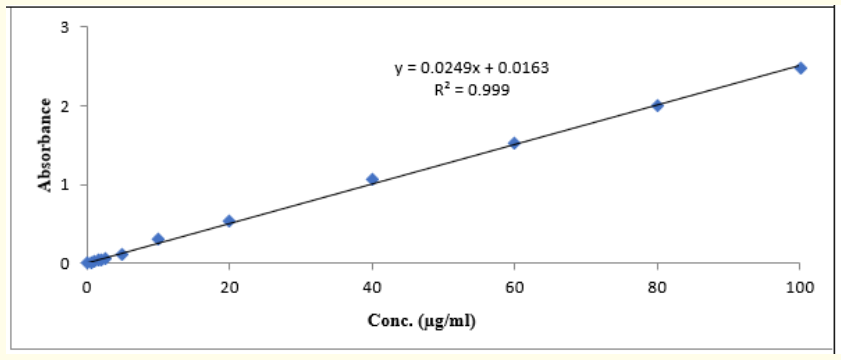

Figure 3C: Calibration curve of Glibenclamide in Phosphate buffer (pH 2.0).

Assay of Glibenclamide tablets

Tablet formulations of two different brands were extracted with the three reagents and separately and the percentage of purity was determined with the help of linear regression equations. The assay was found to be 99.66-99.84, 99.68-99.82 and 99.58-99.92 in borate buffer, phosphate $\mathrm{pH} 8.0$ and phosphate buffer $\mathrm{pH} 2.0$ for Method I, II and III respectively (Table 4). 
Development and Validation of Spectrophotometric Methods for the Determination of Glibenclamide

114

\begin{tabular}{|l|c|c|c|c|c|c|c|}
\hline \multirow{2}{*}{ Brand name } & \multirow{2}{*}{ Label claim (mg) } & \multicolumn{3}{|c|}{ Amount obtained } & \multicolumn{3}{c|}{ \% Recovery } \\
\cline { 3 - 8 } & & Method I & Method II & Method III & Method I & Method II & Method III \\
\hline I & 2.5 & 2.496 & 2.492 & 2.498 & 99.84 & 99.68 & 99.92 \\
\hline II & 5 & 4.983 & 4.991 & 4.979 & 99.66 & 99.82 & 99.58 \\
\hline
\end{tabular}

Table 4: Assay of Glibenclamide tablets.

\section{Conclusion}

The three validated UV spectrophotometric methods were found to be very simple and economical for the regular analysis of Glibenclamide tablets. The percentage RSD in precision and accuracy studies was found to be within the acceptable criteria and the methods are prcise and accurate.

\section{Acknowledgement}

The authors are grateful to M/s GITAM (Deemed to be University), Visakhapatnam for providing the research facilities and Cadila pharmaceuticals Ltd (India) for supplying gift samples of Glibenclamide. There is no conflict of interest.

\section{Bibliography}

1. Christof Schaefer. Drugs during pregnancy and lactation: Hormones and hormone antagonists (Second Edition) (2007).

2. Sönke Rehder., et al., "Thermal degradation of amorphous Glibenclamide". European Journal of Pharmaceutics and Biopharmaceutics 80.1(2012): 203-208.

3. Sudheer Babu I., et al. "Spectrophotometric method development and validation for the estimation of Glibenclamide in pure form and in dosage form". International Journal of Pharmaceutical Sciences and Research 137 (2017): 4925-4928.

4. Sidharth M., et al. "Validated simple and sensitive UV spectrophotometric method for estimation of Glibenclamide in bulk and pharmaceutical formulations". World Journal of Pharmacy and Pharmaceutical Sciences 2.5 (2013): 2627-2634.

5. Abida Bilal., et al. "Development and validation of analytical method for qualitative and quantitative determination of Glibenclamide in different brands of tablet dosage form using UVvisible spectroscopy". Journal of Molecular and Genetic Medicine 7.3 (2013).

6. Amita Rai E., et al. "Development of UV Spectrometric method of Glibenclamide (Glyburide) in bulk and pharmaceutical formulations". International Journal of Chem Tech Research 4.1 (2012): 356-360.
7. Raja Abhilash., et al. "Design and validation of simple UV spectrophotometric method for the assay of Glibenclamide in tablet dosage form". International Journal of Pharmaceutical Biological and Chemical Sciences 2.4 (2013): 52-56.

8. Karim D., et al. "Spectrofluorimetric method for the determination of Glibenclamide In pharmaceutical formulation". Baghdad Science Journal 9.2 (2012): 296-300.

9. Bansal G., et al. "Ultraviolet-photodiode array and high-performance liquid chromatographic/mass spectrometric studies on forced degradation behavior of Glibenclamide and development of a validated stability-indicating method". Journal of AOAC International 91.4 (2008): 709-719.

10. Nazrul Haq., et al. "Rapid analysis of Glibenclamide using an environmentally benign stability-indicating RP-HPLC Method". Iranian Journal of Pharmaceutical Research 13.3 (2014): 863872.

11. Thirunavukkarasu SV., et al. "Development and validation of RP-HPLC method for determination of Glibenclamide in pharmaceutical dosage forms". International Journal of Chem Tech Research 4.2 (2012) 593601.

12. Shiva Teja R., et al. "Estimation of Glibenclamide present in tablets by RP-HPLC". International Journal of Research in Pharmaceutical and Biomedical Sciences 2.2 (2011): 856-862.

13. Narmada D., et al. "RP-HPLC method development and validation for estimation of Glibenclamide in tablet dosage form". Asian Journal of Pharmaceutical Analysis 4.3 (2014): 125-128.

14. Parameswara Rao K., et al. "Development and validation of sensitive RP-HPLC method for the estimation of Glibenclamide in pure and tablet dosage forms". Der Pharmacia Lettre 8.15 (2016):101-106.

15. Mohammad W., et al. "Development and validation of RP- HPLC method for estimation of Glibenclamide in nano emulsion formulation". World journal of pharmacy and pharmaceutical sciences 4.11 (2015): 1579-1587. 
16. Shastri N., et al. "Development and validation of Glibenclamide in nano emulsion formulation by using RP-HPLC". Journal of Pharmaceutical and Biomedical Sciences 8.8 (2011) 1-5.

17. El-Adl., et al. "Design and validation of stability indicating assay of Glibenclamide Using RP-HPLC technique in both bulk, pharmaceutical formulations and human plasma". Journal of Applied Pharmacy 9.4 (2017): 1000250.

18. Khalil I., et al. "High-performance liquid chromatographic method for determination of Glibenclamide in human plasma”. Analytical Letters 27.7 (1994): 1277-1293.

19. Rajendran SD., et al. "RP-HPLC method for the estimation of Glibenclamide in human serum". Indian Journal of Pharmaceutical Sciences 69.6 (2007): 796-799.

20. Validation of Analytical Procedures: Text and Methodology Q2 (R1), International Conference on Harmonization (2005).

Volume 3 Issue 8 August 2019

(C) All rights are reserved by Mukthinuthalapati

Mathrusri Annapurna., et al.

Citation: Mukthinuthalapati Mathrusri Annapurna., et al. "Development and Validation of Spectrophotometric Methods for the Determination of Glibenclamide". Acta Scientific Pharmaceutical Sciences 3.8 (2019): 110-115. 